'Abraham Did not "Doubt" in Unbelief' (rom. 4:20): Faith, Doubt, and Dispute in Paul's Letter to the Romans

\author{
Schliesser, B
}

DOI: https://doi.org/10.1093/jts/fls130

Posted at the Zurich Open Repository and Archive, University of Zurich ZORA URL: https://doi.org/10.5167/uzh-69684

Journal Article

Published Version

Originally published at:

Schliesser, B (2012). 'Abraham Did not "Doubt" in Unbelief' (rom. 4:20): Faith, Doubt, and Dispute in Paul's Letter to the Romans. Journal of Theological Studies, 63(2):492-522.

DOI: https://doi.org/10.1093/jts/fls130 


\title{
'ABRAHAM DID NOT “DOUBT' IN UNBELIEF' (ROM. 4:20): FAITH, DOUBT, AND DISPUTE IN PAUL'S LETTER TO THE ROMANS
}

\author{
Benjamin Schliesser \\ University of Zürich \\ benjamin.schliesser@theol.uzh.ch
}

\begin{abstract}
This article offers an exegetical-theological analysis of Rom. 4:20: 'No dis-

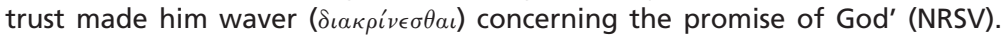
It challenges the common assumption that our customary descriptions and definitions of 'doubt' may be applied-via negativa-to the attitude or

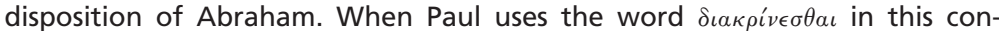
text, he does not intend to say that Abraham's disposition was free from doubt, uncertainty, or hesitation. Rather, Paul had in mind that Abraham did not oppose God in a presumptuous attitude, offend him through conceited enquiries, or question him in order to overturn his word. This interpretation counters the exegetical communis opinio, but has veritable precursors-John Chrysostom, John Calvin, and Markus Barth-and, at the same time, conforms well to the line of thought of Paul's letter. The object of Paul's accusation against Greeks and Jews (Romans 1-3) is less an intrapersonal contradiction or inconsistency rather than an interpersonal conflict between God and human being. Significantly, the contextual argument is supported by a lexicographical fact: The meaning 'to

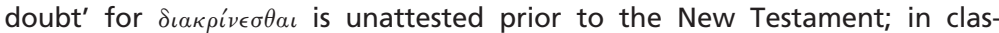
sical/Hellenistic Greek the verb comprises, inter alia, the notions of 'separation' and 'dispute'.
\end{abstract}

'For two millennia, readers of the Christian Scriptures have been fascinated and puzzled by Paul's letter to the Romans. The fascination continues unabated, and readers of the letter continue to approach the text as if it held answers to some of

This essay was presented in various forms at the Universities of Cambridge, Manchester, Durham, and Aberdeen in Oct. 20II and in Toronto and at Notre Dame in Feb. 20I2. Thanks are due to the John Templeton Award for Theological Promise and to all the inviting universities for their welcoming and supportive atmosphere and for the opportunity to present and discuss my argument. I am grateful to all those who participated in the discussions for their probing questions and valuable comments, as well as to the anonymous reviewers of $\mathcal{F T S}$.

(C) The Author 2012. Published by Oxford University Press. All rights reserved. For Permissions, please email: journals.permissions@oup.com doi:10.1093/jts/fls130 
their most profound questions about God [and] God's relation to humanity...'. With these words, Mark Reasoner opens his study on the history of interpretation of Paul's most famous letter; his study seeks to 'give... voice to past conversations on key texts of Romans' and to 'help Romans readers hear how their questions about Romans have been framed, asked, and considered in interpretations of the letter' since the third century. ${ }^{2}$ One such key text is Paul's revolutionary exegesis of Gen. I $5: 6$ in Romans $4{ }^{3}$ which includes-in the words of James Dunn-the 'clearest and most powerful exposition of what he understood by pistis'. ${ }^{4}$ Towards the end of the chapter, Paul obviously tackles one of the most profound questions about God and his relation to humanity: the question of the correlation between 'faith' and 'doubt'. There, Paul's depiction of Abraham's faith includes the following aspect (Rom. 4:20):

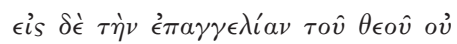
$\delta \iota \epsilon \kappa \rho i \theta \eta \quad \tau \hat{\eta} \dot{\alpha} \pi \iota \sigma \tau \iota_{\imath}^{\prime} \alpha \dot{\alpha} \lambda \lambda^{\prime}$

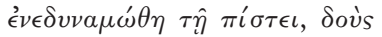
$\delta o ́ \xi \alpha \nu \tau \hat{\varphi} \theta \epsilon \hat{\varphi}$
No distrust made him waver concerning the promise of God, but he grew strong in his faith as he gave glory to God. (NRSV)

For the purpose of this study it is essential to realize what is commonly, in religious and philosophical contexts, considered as 'doubt' or as 'wavering'. Accordingly, the first part deals with descriptions and definitions of 'doubt' by way of a brief look at four symbolic 'conversations' about this phenomenon. The main part of the essay concerns the question: How are we to under-

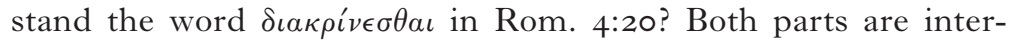
related, for most, if not all modern translations and interpretations render $\delta \iota \alpha \kappa \rho i v \epsilon \sigma \theta \alpha \iota$ with 'doubt', 'waver', or the like. My goal is to dispute the common assumption that our customary descriptions and definitions of 'doubt' may be applied-via negativa-to the attitude or disposition of Abraham in an indiscriminate manner. In short: Paul intended to say something else than 'Abraham did not doubt'.

1 Mark Reasoner, Romans in Full Circle: A History of Interpretation (Louisville, KY: Westminster John Knox, 2005), p. ix.

${ }^{2}$ Ibid.

3 Cf. Benjamin Schliesser, Abraham's Faith in Romans 4: Paul's Concept of Faith in Light of the History of Reception of Genesis I5:6 (WUNT 2/224; Tübingen: Mohr Siebeck, 2007).

4 James D. G. Dunn, The Theology of Paul the Apostle (Grand Rapids, MI: Eerdmans, 1998), p. 377. 


\section{Descriptions and Definitions of 'Doubt'}

What is doubt? Let us listen at first to a literary character, two key figures of modern Geistesgeschichte, and a paradigmatic postmodern individual. In his pastiche of the famous Early Modern novel Don Quixote, Graham Greene tells the story of the priest Monsignor Quixote-purportedly a descendant of the (fictitious) Don Quixote-who is urged by his bishop to take a holiday. ${ }^{5}$ So Quixote is travelling with an old Seat 600 (affectionately called 'Rocinante') through Spain, of course not without being accompanied by 'Sancho Panza', the Communist ex-mayor of his hometown El Toboso. On the trip, the two men engage in dialogues about Catholicism and Communism, and Quixote reflects on his own faith. He is quite sure that some of his parishioners really do keep their Catholic faith, but he himself has to confess: 'I am riddled by doubts. I am sure of nothing, not even of the existence of God, but doubt is not treachery as you Communists seem to think. Doubt is human. Oh, I want to believe that it is all true-and that want is the only certain thing I feel. ${ }^{6}$ This brief episode vividly depicts one aspect of the dialectics of faith and doubt. On the one hand there is a deep longing for certainty - 'Oh, I want to believe that it is all true', and on the other hand not a single element or dogma of the Catholic faith, not even the existence of God, presents itself to him as certain-'I am sure of nothing'. The only certain thing, his fundamentum inconcussum, is precisely the desire 'to believe that it is all true'.

This is different from Martin Luther's 'doubt', his Anfechtung, which overpowers him like a flood and precludes all possibilities of his own action and reaction: the afflicted human being is utterly

5 Graham Greene, Monsignor Quixote (1982) (Penguin Classics; London: Penguin Books, 2008). Cf. Frank D. Rees, Wrestling with Doubt: Theological Reflections on the Fourney of Faith (Collegeville, MN: Liturgical Press, 200r), p. 2.

${ }^{6}$ Greene, Monsignor Quixote, p. I55. To be sure, Quixote takes action against his doubts. 'The habitual way of counteracting doubt for Quixote is rooted in his observance of daily private devotions and the familiar words of the Catholic Tridentine liturgy' (Michael G. Brennan, Graham Greene: Fictions, Faith and Authorship [London and New York: Continuum, 2010], p. I47). Though suspended from his duties, he remains a priest-but a priest only to himself. As for Graham Greene himself, Cedric Watts notes: 'Greene was thoroughly Pyrrhonian: like a devoted follower of the great sceptic, Pyrrho of Elis, he was prepared to be sceptical about scepticism' (Cedric Watts, A Preface to Greene [London and New York: Longman, I997], p. Io6). 
'passive, suffering, accused, convicted'. 7 Doubt forces him to hold on to the promissio dei anew. ${ }^{8}$

Again, this is remarkably different from René Descartes's methodological doubt. Descartes set himself the agenda: de omnibus dubitandum est; doubt for him is intellectual activity, radical method, creative process. He chooses an ideal time of leisure and serenity and decides freely to adjourn to his fireplace in the sitting-room in order to contemplate the philosophical subject of 'doubt'. 'His 'highest expectation' is 'to discover only one thing that is certain and indubitable'. ${ }^{10}$

Post-Enlightenment successors of Descartes represent a dramatic turn: They claim that within the postmodern (or late modern) paradigm one is not entitled to ask for ultimate certainty. In fact, both theology and philosophy are in their view utterly incapable of providing or producing such certainty. They consider the philosophical task not as 'endeavour to annihilate doubts', but as 'endeavour to generate uncertainty' which is to destroy and dissolve all kinds of certainty. ${ }^{11}$

This portrayal of four symbolic 'conversations' and reflections about the phenomenon of doubt represents different types of approaches to and assessments of the experience and practice of doubt. René Descartes, hailed by Hegel as the 'true founder of modern philosophy', ${ }^{12}$ transformed doubt into a radical method of

7 Gerhard Ebeling, 'Gewißheit und Zweifel: Die Situation des Glaubens im Zeitalter nach Luther und Descartes' (1967), in idem, Wort und Glaube, vol. 2: Beiträge zur Fundamentaltheologie und zur Lehre von Gott (Tübingen: Mohr Siebeck, I969), pp. I38-83, at 153 (if not otherwise indicated, translations are mine.).

8 Cf. Helmut Thielicke, Glauben und Denken in der Neuzeit: Die großen Systeme der Theologie und Religionsphilosophie (Tübingen: Mohr Siebeck, I983), pp. $6 \mathrm{I}-2$.

${ }^{9}$ Cf. Ebeling, 'Gewißheit und Zweifel', p. I 53: 'ut jam me hic esse, foco assidere, hiemali esse indutum.'

10 Meditationes 2. I (trans. John Veitch).

11 Andreas Urs Sommer, Die Kunst des Zweifelns: Anleitung zum skeptischen Philosophieren (Beck'sche Reihe I664; 2d edn.; München: Beck, 2007), p. ıо; cf. idem, 'Religionsverzicht um des guten Lebens willen? Eine skeptische Übung', Hermeneutische Blätter I/2 (20II), ed. A. Hunziker and B. Schliesser, pp. I $35^{-46}$.

12 Georg Wilhelm Friedrich Hegel, 'Vorlesungen über die Geschichte der Philosophie. Dritter Band', in Sämtliche Werke, vol. I9, ed. H. Glockner (repr. Stuttgart-Bad Cannstatt: Friedrich Frommann, I959), p. 33 I ('René Descartes ist in der Tat der wahrhafte Anfänger der modernen Philosophie, insofern sie das Denken zum Princip macht.' Hegel adds [p. 335]: 'Und daß nur vom Denken angefangen werden müsse, drückt er so aus, daß man an Allem zweifeln müsse'-hence, the principle of thinking manifests itself at first in the principle of doubting). 
rational selection and insisted that only indubitability establishes truth $^{13}$ and thus sought to overturn scepticism. ${ }^{14}$ Martin Luther, who marks-again according to Hegel—the beginning of the freedom of the spirit, ${ }^{15}$ experienced 'doubt' as a disastrous, forced rather than 'free' state of the spirit, which constantly and acrimoniously fights against certitude. ${ }^{16}$ The two are framed, on the one hand, by the literary character Monsignor Quixote, the somewhat cynical renegade priest, for whom doubt is human and a 'traveling companion' of faith, ${ }^{17}$ and on the other hand, by the modern-day sceptic, for whom 'doubt' has become a 'signature of human maturity', ${ }^{18}$ a part of his or her modus vivendi, indeed ars vivendi.

All four, however, share a common idea when they speak of doubt: the split of a person's heart or mind into two parts. ${ }^{19}$ This is reflected in both the Romance and Germanic words for 'doubt', for in all these languages, the element of 'two-ness' is decisive: 'dubitatio', 'le doute', 'la duda', 'il dubbio', 'Zweifel', and 'doubt' are all words that include the numeral 'two'. ${ }^{20}$ English dictionaries, for instance, define 'doubt' as 'a feeling or attitude that one does not know the truth, truthfulness, or trustworthiness of someone or something'; ${ }^{21}$ and they offer a range of meanings that all converge in the idea of 'two-ness': ' $\mathbf{a}$ : an uncertainty of belief or opinion that often interferes with decision-making $b$ : a deliberate suspension of judgment 2: a state of affairs giving rise to uncertainty, hesitation, or suspense $3 \mathrm{a}$ : a lack of confidence: distrust b: an inclination not to believe or accept. ${ }^{22}$ Thus, the etymology of these nouns duly demonstrates that the one who doubts finds him- or herself in a state of uncertainty or diffidence,

13 Cf. Janet Broughton, Descartes's Method of Doubt (Princeton: Princeton University Press, 2002), pp. I66-8.

14 René Descartes, Objectiones VII (I642), ed. C. Adam and P. Tennery, 7,550: 'scepticorum dubitationem.... everti.'

15 Hegel, 'Vorlesungen über die Geschichte der modernen Philosophie', p. 254 .

16 'Pugnant autem haec duo acerrime inter se, certitudo et dubitatio' (WA 39 II, I63).

${ }^{17}$ Cf. Espen Dahl, In Between: The Holy Beyond Modern Dichotomies, trans. Brian McNeil (Research in Contemporary Religion, 6; Göttingen: Vandenhoeck \& Ruprecht, 20II), p. I52.

18 Thielicke, Glauben und Denken, p. 63.

19 Cf. Rees, Wrestling with Doubt, p. 2.

20 Cf. Gunther Zimmermann, “An Gott zweifeln"-eine logische Untersuchung', Neue Zeitschrift für Systematische Theologie 48 (2006), pp. 305-20, at 307.

21 Merriam-Webster online; <http:/www.merriam-webster.com/thesaurus/ doubt $\% 5$ Bnoun $\left.\%_{5} \mathrm{D}\right)>$.

22 Merriam-Webster's Collegiate Dictionary, IIth edn. (2003), p. 375. 
since he or she has two conflicting attitudes towards a certain subject-matter. He or she does not contest or refute it in its entirety, but at the same time does not affirm it wholeheartedly. It is an intrapersonal conflict between two positions, both of which might possibly be true. ${ }^{23}$

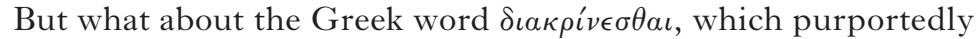
informs us most properly on the New Testament idea of 'doubt'? It occurs in prominent passages such as Mark I I:23 where Jesus says (NRSV): 'Truly I tell you, if you say to this mountain, "Be taken up and thrown into the sea", and if you do not doubt in your heart, but believe that what you say will come to pass, it will be done for you.' The other occurrences are spread throughout the New Testament, mostly having the noun $\pi i \sigma \tau \iota s$ in their immediate

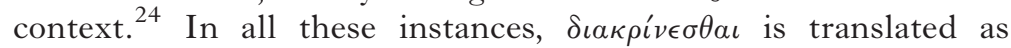
'doubt' (or the like) in virtually all modern translations, no matter which language. And almost all commentaries follow and support this translation practice. In the following, this opinio communis will be scrutinized in the light of the descriptions and definitions of 'doubt' presented in this section, by exploring the use of the verb $\delta \iota \alpha \kappa \rho \imath \nu \in \sigma \theta a \iota$ in Rom. 4:20.

\section{Paul's Use of the Verb}

As already mentioned, James Dunn noted that in Rom. 4:182 I(22), Paul presents the 'most powerful exposition' of what he understood by 'faith'. ${ }^{25}$ Faith's counterpart, doubt, purportedly occurs in Paul's statement that 'Abraham did not "doubt" in

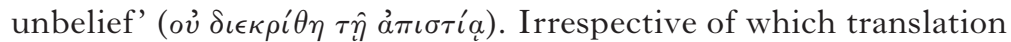
of Romans one is consulting, the notion of 'doubt' or 'hesitation' or 'wavering' is unanimously present, even as early as in the Vulgate. A random selection of translations illustrates this fact:

Vulgate: 'non haesitavit diffidentia'

Luther: 'Denn er zweifelte nicht... durch Unglauben'

Segond 2r: 'Il n'a pas douté, par incrédulité'

KJV: 'He staggered not...through unbelief'

NRSV: 'No distrust made him waver'

23 This follows closely Zimmermann, “'An Gott zweifeln”, , p. 307.

24 Matt. 21:2I; Mark Ir:23; Rom. 4:20; I4:23; Jas. I:6; Jude 20-2; cf. in addition-without the correlate $\pi i \sigma \tau \iota \varsigma-A c t s$ 10:20. Apart from these passages, $\delta \iota а к \rho i v \in \sigma \theta a \iota$ occurs in Jas. 2:4; Jude 9; Acts II:2, where the meaning 'dispute' or the like is assumed; see in addition Acts II:I2 (v.l.: Byzantine text) and

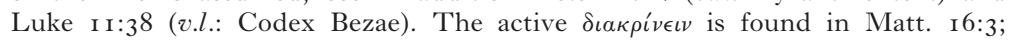
Acts II:I2; I 5:9; I Cor. 4:7; 6:5; II:29, 3I; I4:29.

25 Dunn, Theology of Paul, p. 377. 


\section{I. A Philological Perplexity}

However, a comparison of the alleged New Testament meaning with the semantics of the medio-passive $\delta \iota \alpha \kappa$ ív $\epsilon \theta \alpha \iota$ in classical/Hellenistic Greek reveals a perplexing fact: There is no evidence prior to the New Testament that $\delta \iota \alpha \kappa \rho i v \epsilon \sigma \theta a \iota$ takes on the meaning 'doubt' or the like. Lexica list three semantic fields for this verb in classical/Hellenistic Greek: ${ }^{26} \mathrm{I}$. to be separated or to be dissolved (into elements), 2. to come to a decision or to get it decided, and 3. to contend or to dispute. As for the active

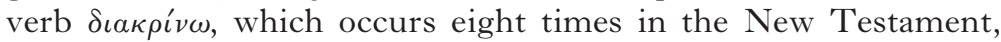
scholars use translations that remain within the verb's 'classical/ Hellenistic Greek parameters, i.e., discern, decide, or separate'.

Most recent New Testament lexicography proposes that one is to follow "[a] thoroughly diachronic approach that includes the later phases of the Greek language ... to provide a more complete understanding of the vocabulary of the New Testament'. ${ }^{28}$ This approach, however, does not alter, but rather intensifies, the sense of perplexity with respect to the verb in question. A pioneer of this approach, Chrys Caragounis maintains that

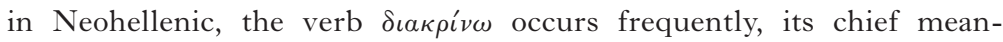
ings being to discern, to distinguish, to characterize. The medio-passive

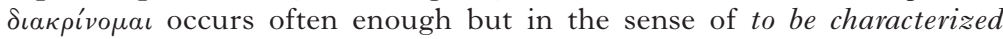
$b y$, to be distinguished, e.g. of a scientist, an athlete who distinguishes himself through his achievement, etc.... This goes for both Katharevousa and Demotike... In Neohellenic the New Testament

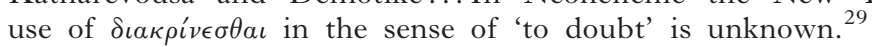

Notwithstanding these lexicographical facts, Joachim Jeremias stated in an important paper on the line of thought

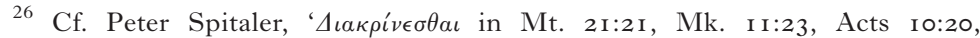
Rom. 4:20, I 4:23, Jas. I:6, and Jude 22-the "Semantic Shift" that Went Unnoticed by Patristic Authors', NT 49 (2007), pp. I-39, at I-2, n. 2. Spitaler refers to the dictionaries of Franz Passow, Handwörterbuch der Griechischen Sprache, vol. I: $A-D$ (Darmstadt: Wissenschaftliche Buchgesellschaft, I970), and Henry George Liddell and Robert Scott, $A$ Greek-English Lexicon, rev. Henry Stuart Jones (9th edn.; Oxford: Clarendon Press, I996). He adds that in the New Testament 'only Acts II:2, Jas. 2:4, and Jude 9 are said to reflect classical/Hellenistic meaning'.

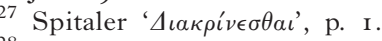

28 David S. Hasselbrook, Studies in New Testament Lexicography: Advancing toward a Full Diachronic Approach with the Greek Language (WUNT 2/303; Tübingen: Mohr Siebeck, 20II), p. I4. Hasselbrook names as predecessors of this 'full diachronic approach' Georgios N. Hatzidakis, Chrys C. Caragounis, and John A. L. Lee.

${ }^{29}$ Chrys C. Caragounis (private correspondence, 20 Aug. 20II). However, he does not concur with me in my critique of the lexicographical status quo. 


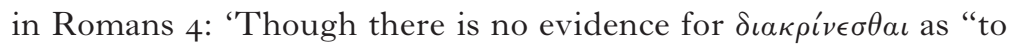
doubt" or "to hesitate" prior to the New Testament, this meaning is so strongly attested in the New Testament that the translation "to doubt" is based on solid ground." 30 According to Jeremias, the meaning of the passage is as follows: 'Abraham has nothing but the promise. But he considers God's word to be most certain and firm. He clings to the word. He believes in it without being deterred. With this undeterred trust he gave glory to God.'31 Jeremias's point of reference is Bauer's dictionary, which concedes that the meaning 'to have reservations, to doubt' appears first in the New Testament. ${ }^{32}$ It insinuates that the shift of meaning manifesting itself in the New Testament emerges from one basic classical/Hellenistic meaning of the word: The outward activity of contending or disputing (i.e. the classical/Hellenistic meaning) is transformed into the internal activity of 'contending or disputing with oneself', from which the meaning 'to doubt' can be deduced. ${ }^{33}$ This description goes back at least as far as to 'the beginning of modern scientific lexicography', ${ }^{34}$ namely to Christian Abraham Wahl's Clavis Novi Testamenti philologica. ${ }^{35}$

Some even interpret this specific New Testament development as a proof for the uniqueness of the New Testament Greek oras does Friedrich Büchsel in his TDNT article-as an example for the power of the Gospel to produce language. ${ }^{36}$

30 Joachim Jeremias, 'Die Gedankenführung in Röm 4: Zum paulinischen Glaubensverständnis', in Foi et Salut selon S. Paul: Épittre aux Romains I,I6. Colloque oecuménique à l'abbaye de S. Paul hors les murs, I6-2I avril I968 (AnBib 42; Rome: Institut biblique pontifical, I970), pp. 5I-8 (and discussion with Eduard Schweizer, Markus Barth, Rudolf Pesch, Jules Cambier, Stanislas Lyonnet, and W. C. van Unnik, pp. 59-65), at 56.

31 Jeremias, 'Die Gedankenführung in Röm 4', p. 57.

32 Walter Bauer, Griechisch-deutsches Wörterbuch zu den Schriften des Neuen Testaments und der frühchristlichen Literatur, ed. K. Aland and B. Aland (6th edn.; Berlin and New York: de Gruyter, I988), p. 370.

33 Ibid.

34 Frederick W. Danker, Multipurpose Tools for Bible Study (rev. and exp. edn.; Minneapolis, MN: Fortress, I993), p. г го.

${ }^{35}$ Christian Abraham Wahl, Clavis Novi Testamenti philologica: Usibus scholarum et iuvenum theologiae studiosorum accommodate ( 1822 ) (2nd edn.; Leipzig: Johann Ambrosius Barth, I 829), p. 285: 'ich bin mit mir selbst im Streite'. Cf. Christianus Gottlob Wilke, Clavis Novi Testamenti philologica: Usibus scholarum et iuvenum theologiae studiosorum accommodate, vol. I (Dresden and Leipzig: Libraria Arnoldiana, I84I), p. 220: 'dubito (in contrario discerno, ut dubius haeream, Utrum eligam, sich mit sich entzweien)'.

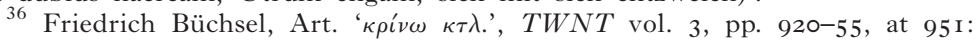

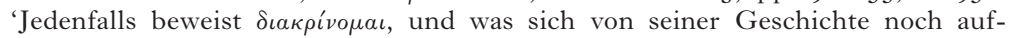
hellen läßt, die sprachbildende Kraft des Evangeliums.' 
This terminology obviously alludes to the methodological principle of the forerunner of the TDNT, Hermann Cremer's Biblico-Theological Lexicon of New Testament Greek. In the introduction Cremer maintains that it is his goal to produce a lexicon which recognizes "what Schleiermacher calls "the languagemoulding power of Christianity", 37 and which seeks to uncover the 'inner', spiritual meaning of words.

According to Adolf Deissmann, this is an illegitimate philological approach, and he attacked Cremer's methodology head on. He showed in his Bible Studies ${ }^{38}$ that the authors of the New Testament did not use a particular, possibly even inspired Greek. Rather than the 'language of the Holy Ghost' they were using Koine Greek, 'the lingua franca of the whole Roman Empire by the first century CE' ${ }^{39}$ As Deissmann himself contended in his 'Selbstdarstellung', it was his goal to 'secularize dogmatic Philologia sacra': ${ }^{40}$ 'This is how it came to my Bibelstudien (I895) and Neue Bibelstudien (I897). Above all, their impact was to free the special "Biblical Greek" from its solitary confinement, after having been unnecessarily and vigorously isolated by theologians and philologists. ${ }^{41}$ Deissmann intended to merge the results of his studies into a large-scale dictionary of the New Testament ${ }^{42}$ - a plan that he eventually could not carry out due to his overwhelming teaching responsibilities, the turbulences surrounding the First World War and his focus on other

\footnotetext{
37 Hermann Cremer, Biblico-Theological Lexicon of New Testament Greek, trans. William Urwick (Edinburgh: $T$ \& $T$ Clark, i 895 ), p. iv. One could rightly ask if Cremer cited Schleiermacher's phrase 'die sprachbildende Kraft des Christenthums' appropriately (see below, n. 50).

38 Adolf Deissmann, Bibelstudien: Beiträge, zumeist aus den Papyri und Inschriften, zur Geschichte der Sprache, des Schrifttums und der Religion des hellenistischen Fudentums und des Urchristentums (Marburg: Elwert, I 895); idem, Neue Bibelstudien: Sprachgeschichtliche Beiträge, zumeist aus den Papyri und Inschriften, zur Erklärung des Neuen Testaments (Marburg: Elwert, I 897). Both studies appeared in English translation as Bible Studies: Contributions Chiefly from Papyri and Inscriptions to the History of the Language, the Literature, and the Religion of Hellenistic Fudaism and Primitive Christianity, trans. Alexander Grieve (I90I) (2nd edn.; Edinburgh: T \& T Clark, I909).

39 Daniel B. Wallace, Greek Grammar beyond the Basics: An Exegetical Syntax of the New Testament (Grand Rapids, MI: Zondervan, I996), p. I8.

40 Adolf Deissmann, 'Adolf Deissmann', in Die Religionswissenschaft der Gegenwart in Selbstdarstellungen, ed. E. Stange (Leipzig: Meiner, 1925), pp. $42-78$, at 62 .

41 Ibid., pp. 53-4; cf. Albrecht Gerber, Deissmann the Philologist (BZAW

I7I; Berlin and New York: de Gruyter, 2010), p. 27.

42 Expressed, for instance, in Deissmann, Neue Bibelstudien, p. vii.
} 
academic and church-political matters. ${ }^{43}$ Deissmann viewed very critically the publication of Erwin Preuschen's Handwörterbuch'a great and painful disappointment ${ }^{\text {'4 }}$ - though years later he applauded the third edition of Walter Bauer's reworking of Preuschen's lexicon from I 936 as 'a most gratifying event in the realm of both the academy and the church'. ${ }^{45}$

However, although Bauer significantly improved Preuschen's work in accordance with Deissmann's philological principles and incorporated new documentary evidence, 'the semantic content of the underlying work of Preuschen was preserved with little modification'. ${ }^{46}$ This is also true for the entry on the verb $\delta \iota \alpha \kappa \rho i v \epsilon \sigma \theta a$. Bauer took over almost literally Preuschen's entry and he even adds that the meaning 'to doubt etc.' is only documented from New Testament times onwards. ${ }^{47}$

In sum, the 'philological perplexity' concerning $\delta \iota \alpha \kappa$ i $v \in \sigma \theta a \iota$ results from (I) the postulate that $\delta \iota \alpha \kappa \rho i v \in \sigma \theta \alpha \iota$ takes on a 'special New Testament meaning' not found in contemporary texts, i.e. that it is a 'product of Greek-speaking Christianity ${ }^{48}$; (2) the alternative attempt that derives the meaning 'to doubt' from a hypothetical 'semantic development of Greek popular speech in New Testament times'; ${ }^{49}$ (3) the assumption that this new, unprecedented, and unparalleled meaning occurs not only in one of the New Testament authors, but across the New Testament, in different genres and in a variety of contexts (Matt. 21:2I; Mark II:23; Acts I0:20; Rom. 4:20; I4:23; Jas I:6; Jude 20-2) - even though at least one common term for this phenomenon would have been at hand: $\delta \iota \sigma \tau \alpha \dot{\alpha} \epsilon \iota \nu$ (cf. Matt. I 4:3 I ; 28:I 7).

43 Cf. Gerber, Deissmann, pp. 9I-Io3.

44 Thus in the review of the first fascicle (quoted in Gerber, Deissmann, p. 93).

45 Quoted in Gerber, Deissmann, p. Iоo.

46 John A. L. Lee, A History of New Testament Lexicography (Studies in Biblical Greek; New York: Lang, 2003) p. I 5 I.

47 Erwin Preuschen and Walter Bauer, Griechisch-Deutsches Wörterbuch zu den Schriften des Neuen Testaments und der übrigen urchristlichen Literatur (2nd edn.; Giessen: Töpelmann, I928), p. 289 ('in dies[er] Bedeut[un]g erst seit $\mathrm{d}[\mathrm{em}]$ NT nachweisbar'). This might go back to Joseph $\mathrm{H}$. Thayer, $A$ Greek-English Lexicon of the New Testament: Being Grimm's Wilke's Clavis Novi Testamenti (corrected edn.; New York: Harper \& Brothers, i889), p. I 38 ('in a sense not found in prof[ane] auth[ors]').

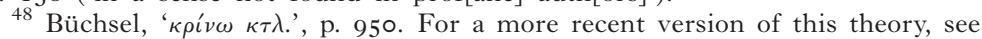
Robert Jewett, Romans: A Commentary (Minneapolis, MN: Fortress, 2007),

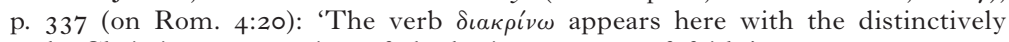
early Christian connotation of doubt in a matter of faith.'

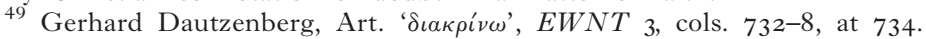


To be sure, Deissmann himself maintained that the authors of the New Testament writings do testify to unique word meanings and specific semantic developments:

It is of course true that the language of the early Christians contained a series of religious terms peculiar to itself, some of which it formed for the first time, while others were raised from among expressions already in use to the status of technical terms. But this phenomenon must not be limited to Christianity: it manifests itself in all new movements of civilization (Kulturbewegungen). The representatives of any peculiar opinions are constantly enriching the language with special conceptions (individuelle Begriffe). ${ }^{50}$

Furthermore, it is also true that in later centuries the meaning

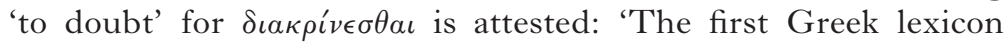

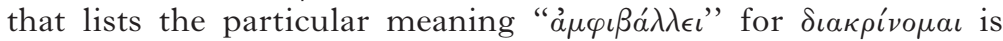
authored by Photius [Constantinopolitanus] (9th century CE).' His entry for $\delta \iota \alpha \kappa \rho i ́ v \epsilon \tau a \iota$ lists as synonyms: $a \dot{\mu} \varphi \iota \beta a ́ \lambda \lambda \epsilon \iota, \dot{a} \pi \iota \sigma \tau \epsilon \hat{\imath}$, and $\delta \iota a x \omega \rho i \zeta_{\epsilon \tau a \iota .}{ }^{51}$ The question therefore is: did the Christian 'movement of civilization' forge or adopt a 'special conception' of $\delta \iota \alpha \kappa \iota^{\prime} \in \epsilon \theta a \iota$ at its very beginning or is it more plausible that the early Christian use of $\delta \iota \kappa \rho \iota \iota v \epsilon \sigma \theta a \iota$ reflects the common linguistic usage of that time?

\subsection{No 'Special Meaning'}

Eventually, it has been merely a matter of time that scholars cast doubt on the common etymological and semantic explanations that propagate a 'semantic shift' or 'semantic development' in the texts of the New Testament. A small number of alternative approaches, therefore, refrain from postulating this hypothesis and attempt to explain the relevant passages within the paradigm of the classical/Hellenistic categories of meaning. ${ }^{52}$

${ }^{50}$ Deissmann, Bible Studies, p. 65 note $\mathrm{I}=$ Bibelstudien, p. 59 note. This is actually the context of Schleiermacher's phrase 'die sprachbildende Kraft des Christenthums': 'Jede geistige Revolution ist sprachbildend, denn es entstehen Gedanken und reale Verhältnisse, welche eben als neue durch die Sprache, wie sie war, nicht bezeichnet werden können.' (F. D. E. Schleiermacher, Hermeneutik und Kritik, ed. M. Frank [Suhrkamp Taschenbuch Wissenschaft, 2II; Frankfurt am Main: Suhrkamp, I977], p. I I5).

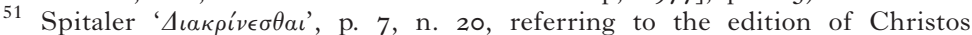
Theodoridis, Photii Patriarchae Lexicon, vol. I: $A-\Delta$ (Berlin and New York: de Gruyter, I982). On ả $\mu \varphi \imath \beta a ́ \lambda \lambda \epsilon \iota v$ see however below, n. 6r.

${ }_{52}$ See Norbert Baumert, 'Das paulinische Wortspiel mit креv-', Filología neotestamentaria I5 (2002), pp. I9-64; David DeGraaf, 'Some Doubts about

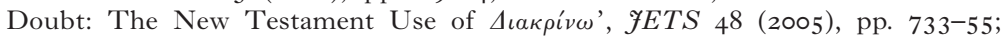
Peter Spitaler, 'Doubt or Dispute (Jude 9 and 22-23): Rereading a Special 
In a series of articles Peter Spitaler ascribes the alleged 'semantic shift' not to a specific New Testament development of the verb $\delta \iota \alpha \kappa i^{\prime} \nu \epsilon \sigma \theta \alpha$, but regards it as a product of a process of translation and interpretation setting in with Origen and Chrysostom. 'Origen and Chrysostom see a relationship between the words doubt and dispute although neither author interprets one word (i.e. doubt or dispute) to have the same meaning as the other.' Spitaler concludes his essay—programmatically subtitled 'the "Semantic Shift" that Went Unnoticed by Patristic Authors'-

with the recommendation that the common Greek language system be

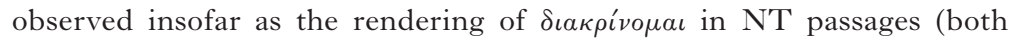
inside and outside of the NT) is concerned. For a special NT meaning of this verb to be valid, each literary context needs to reveal that its author has expanded the middle voice's horizon of meaning. This can be shown to have occurred with the help of negative proof, i.e. if none of the traditional meanings of the middle voice sufficiently explains the clause containing the middle, it is reasonable to posit a modification of meaning. Cross-referencing NT passages does not prove a genuine semantic development. If both the clause containing

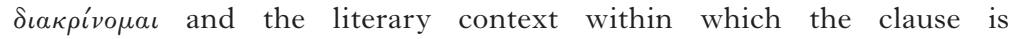
embedded support a traditional meaning of the verb, an argument for a semantic shift is without merit; a rendering of the verb according to classical/Hellenistic Greek conventions needs to be pursued. ${ }^{53}$

In my opinion it is indeed illuminating to follow the path prepared by Spitaler and consult interpreters of the Early Church in order to utilize their original Sprachgefühl and linguistic competence. But I will amplify his approach by adding two other interpreters whose exegesis appears to be sensitive to the relevant philological and lexicographical issues and who do not subscribe uncritically to the interpretative convention. It seems to me that the insights of John Chrysostom, John Calvin, and Markus Barth are capable of shedding new light on this key text in Romans and also on the profound question about 'faith' and its antagonist. Their approaches all deserve attention on their own account, but furthermore, I believe it is possible to demonstrate that they build upon each other and thus afford a

New Testament Meaning through the Lens of Internal Evidence', Biblica 87

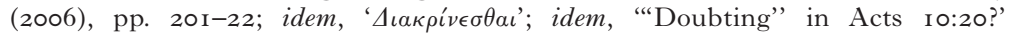
Filología neotestamentaria 20 (2007), pp. 8I-94; idem, 'James I:5-6, a Dispute with God', $C B Q 7$ I (2009), pp. 560-79. See also the older article by F. C. Synge, 'Not Doubt, but Discriminate', ExpTim 89 (I978), pp. 203-5.

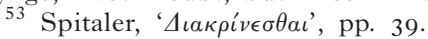


remarkable insight into the history of interpretation of a particular phrase of Paul's letter. On the basis of the comments of Chrysostom, Calvin, and Barth, my own tentative approach to the meaning of $\delta \iota \kappa \iota^{\prime} \nu \epsilon \sigma \theta a \iota$ in Rom. 4:20 will be presented at the end. ${ }^{54}$

\subsection{An Exegesis of Romans 4:20}

\subsection{Fohn Chrysostom}

Not long after his death in the year AD 407, Chrysostom's exegesis of Paul has already been hailed as unsurpassable. The fifth-century Egyptian ascetic monk Isidore of Pelusium remarked that if the divine Paul had taken up the Attic tongue to interpret himself, he would not have done it differently than this renowned man has done' ${ }^{55}$ Even contemporary scholarship shows utmost respect for the philological, exegetical, but also pastoral impulses and insights contained in Chrysostom's treatises and homilies. Margaret Mitchell says: 'As a rhetorically trained, Greek-speaking Syrian,... Chrysostom knew intimately well the literary culture in which Paul was situated. Therefore, his abundant comments on Paul's rhetorical proficiency and crudities are of paramount importance for current research into the rhetoric of Paul's epistles.' She adds, however, that 'these statements need to be subjected to a careful analysis in the light of Chrysostom's own rhetorical purposes and goals, something which has been insufficiently attended to in the appropriation of Chrysostom into contemporary New Testament scholarship on a range of exegetical and philological issues'. ${ }^{56}$

Precisely his exposition of Abraham's faith, which figures in several places, ${ }^{57}$ illustrates both the accurate philological and the pragmatic character of his exegetical efforts. In spite of the different emphases displayed in Chrysostom's comments on Rom. 4:20, his main objective is quite clear: 'Chrysostom expressed deep concern about a widespread tendency to meddle $(\pi \epsilon \rho \iota-$ $\epsilon \rho \gamma a \dot{\zeta} \epsilon \sigma \theta \alpha \iota, \pi o \lambda v \pi \rho \alpha \gamma \mu o v \epsilon \hat{\imath} \nu)$ in forbidden knowledge of the divine nature. For Chrysostom, pistis alone protected against such prying curiosity because it set boundaries without which

54 The case of Rom. I $4: 23$ is to be dealt with separately.

55 Margaret Mitchell, The Heavenly Trumpet: Fohn Chrysostom and the Art of Pauline Interpretation (HUT 40; Tübingen: Mohr Siebeck, 2000 and Louisville, KY: Westminster John Knox, 2002), p. 3 I.

56 Ibid., p. 30.

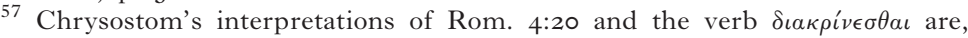

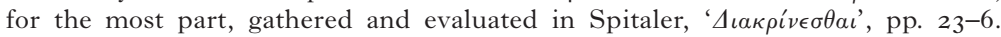


an investigation could easily degenerate into an infinite regress of questions and responses. ${ }^{58}$

In his ninth homily to Paul's letter to the Romans ${ }^{59}$ Chrysostom praises the faith of Abraham, who believed 'against the hope of man in the hope of God'. Paul's words that 'No distrust made him waver concerning the promise of God', Chrysostom explains in terms of the opposition between a human and a divine viewpoint:

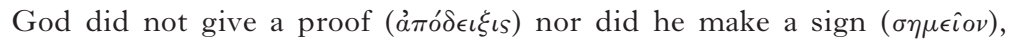
but there were only bare words ( $\dot{\rho}^{\prime} \mu \alpha \tau \alpha \psi\left(\iota \lambda \alpha^{\prime}\right)$ promising such things

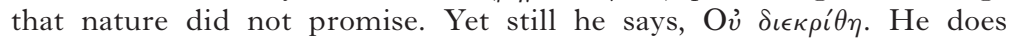
not say, 'He did not disbelieve', but, O $v$ $\delta \iota \epsilon \kappa \rho ' \theta \eta$, that is, he did not

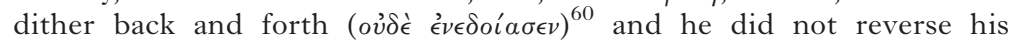
position (ov̉ó̀ $\left.\dot{a} \mu \varphi \epsilon^{\prime} \beta a \lambda \epsilon\right)^{61}$ though the hindrances were so great. From this we learn, that if God promises even countless impossibilities, and he that hears does not receive them, it is not the nature of things that is to blame, but the unreasonableness ( $\left.\alpha^{\prime} \nu o \iota \alpha\right)$ of him who receives them (sc. the promised impossibilities) not.

Chrysostom's primary focus is not a potentially doubtful, hesitant, or questioning inward reflection about God's words, which grapples (intellectually) with the impossibility of the promised

58 Richard Lim, Public Disputation, Power, and Social Order in Late Antiquity (The Transformation of the Classical Heritage, 23; Berkeley: University of California Press, I995), p. I74 (also cited in Spitaler,

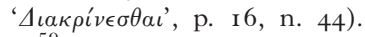

${ }^{59}$ Text in PG 60, 46I (in PG this homily is numbered as the eighth homily, but most German and English translations count the introduction as first homily). The English translation follows Saint Chrysostom: Homilies on the Acts of the Apostles and the Epistle to the Romans, trans. J. Walker, J. Sheppard, and H. Browne, rev. George B. Stevens, vol. I/I I of $A$ Select Library of the Nicene and Post-Nicene Fathers of the Christian Church, ed. P. Schaff (Buffalo, NY: Christian Literature, I889).

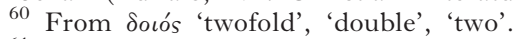

${ }^{61}$ In biblical usage (LXX and NT) ả $\mu \varphi \iota \beta a ́ \lambda \lambda \lambda_{\epsilon \nu}$ means to 'cast, a t.t. for the throwing out of the circular casting-net' (BDAG, p. 54) (Hab. I: I7; Mark I:I6; cf. Isa. I 9:8). According to a number of dictionaries, already Aristotle, Ethica Eudemia $1243^{\mathrm{a}} \mathrm{I} 2.25$ used this verb with the meaning 'to doubt' (cf. Stefan Lorenz, Art. 'Zweifel', Historisches Wörterbuch der Philosophie I 2, pp. 1520-7, at $\mathrm{I}_{520}$ ) or 'to be doubtful' (LSJ, pp. 89-90). However, whereas the text in $\mathrm{I} 243^{\mathrm{a}} \mathrm{I} 2$ itself is indeed doubtful, the context in $\mathrm{I} 243^{\mathrm{a}} 25$ rather suggests something like a change or reversal of one's position. Cf. Harris Rackham, The Athenian Constitution. The Eudemian Ethics. On Virtues and Vices (LCL 285; Cambridge, MA: Harvard University Press, I935), p. 425: 'the position is

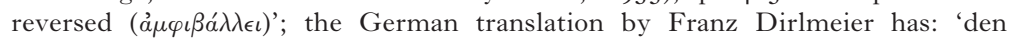
Standpunkt wechseln' (Eudemische Ethik [4th edn.; Berlin: Akademie-Verlag, I984], pp. 86-7). This meaning makes good sense in the context of Chrysostom's homily. 
things, but rather a potentially foolish and disrespectful reaction to God's words, which impairs the integrity of one's relationship with God. This focus becomes even more evident in the following, when Chrysostom describes what Abraham did: He 'gave glory to God; and was fully persuaded that, what he had promised, he was able also to perform'. Chrysostom's explanation of this passage features the already mentioned motif that characterizes and specifies his perception of what it means not to dither back and forth and not to reverse one's position: it is a wholehearted and unconditional devotion to God, which is not indul-

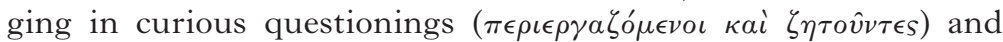
which is not overcurious ( $\pi \circ \lambda v \pi \rho a \gamma \mu o \nu o v v \tau \epsilon S)$ in matters of the mysteria divinitatis. For, such insolence $(\hat{v} \beta \rho i \zeta o v \tau \epsilon s)$ will cause utmost suffering.

The ideas of curious questioning and immoral meddling with which Chrysostom illustrates Abraham's attitude permeate virtually all of his writings and can be found in a number of different contexts. In all these passages he warns his readers not to deal with the divine in a sinful manner by not accepting their human confinements. Generally,

[t]he verb $\pi \epsilon \rho \iota \epsilon \rho \alpha \dot{\zeta} \epsilon \sigma \theta \alpha \iota$ and the verb $\pi \circ \lambda v \pi \rho a \gamma \mu o v \epsilon \hat{v} v$ constitute a couple that is rarely disjoined. The two composite forms of these two words only differ in their prefix-the one underlining the multiplicity of the questions asked,...the other the multiple variations of approaching a subject-matter...Both, however, share a pejorative overtone, for this activity is entirely in vain-its object is beyond human understanding. ${ }^{62}$

Once he remarks that if God reveals things that may not be questioned ( $\stackrel{o}{\mu} \mu \dot{\eta} \delta \epsilon \hat{\imath} \pi \circ \lambda v \pi \rho a \gamma \mu o \nu \in \hat{\imath} \sigma \theta \alpha \iota$ ), such things need to be accepted in faith. Meddling $(\pi \epsilon \rho \iota \epsilon \rho \gamma a ́ \zeta \epsilon \sigma \theta \alpha \iota)$ in the causes of these revelations and investigating $(\dot{\alpha} \pi \alpha \iota \tau \epsilon \hat{\imath} \nu)$ their claim to truth and scrutinizing $(\dot{\epsilon} \pi \iota \eta \eta \tau \epsilon \hat{\imath} \nu)$ their realization-this is the work of a shameless and reckless soul. ${ }^{63}$

62 fean Chrysostome. Sur l'incompréhensibilité de Dieu. Homélies I-V, text, apparatus, and notes by Anne-Marie Malingrey, trans. Robert Flacelière, introduction by Jean Daniélou (SC 28; 2nd edn.; Paris: Cerf, I970), p. I29, n. 5 (on De incomprehensibili natura Dei 1.322). Cf. p. I48, n. 2 (on De incomprehensibili natura Dei 2.76-7, in the context of which [2.53-148] Zacharias is compared to the Anhomeans, who seek to explore the mystery of Christ's birth (2.14I): 'On retrouve dans ce passage le thème majeur des homélies: opposition entre l'enquête qui se mêle de ce qui ne la regarde pas:

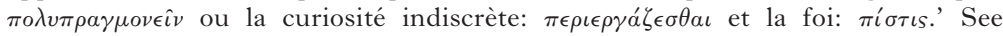

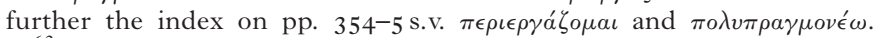

${ }^{63}$ De incomprehensibili natura Dei 2.77-9 (SC 28, pp. I48-9). 
All this sheds light on Chrysostom's understanding of the

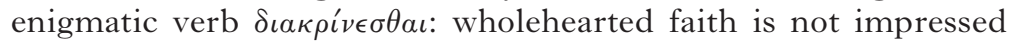
with human limitations since it is directed to the one who gives and fulfils the promise; on the other hand it does accept human limitations as it does not meddle in God's affairs and does not with a bumptious attitude oppose God. To be sure, Chrysostom's exegesis without doubt serves his 'own rhetorical purposes and goals ${ }^{64}$ - if Abraham lived in our days he would not be overcurious in the matter of the Lord's birth as the Anhomeans are ${ }^{65}$-but the 'philological' aspect does not seem to be affected by his apparent pedagogical or church political application. Rather, his understanding of $\delta \iota \alpha \rho^{\prime} \nu \epsilon \sigma \theta \alpha \iota$ based on his profound knowledge of Paul's literary milieu constitutes the premise of his own rhetorical purpose.

\subsubsection{Fohn Calvin}

John Calvin's thinking, too, is shaped by a specifically ecclesial impetus. He pushes for a reform of the church and is at the same time deeply rooted in the theological tradition of the early church. His scriptural exposition is

decisively influenced from the 'Christian humanism' at the beginning of the sixteenth century. Already in Paris he becomes acquainted with the ideals of 'Bible humanism' and begins himself to explain the Bible based on the biblical languages... To a great degree he took over the philological and text-critical insights of Erasmus. ${ }^{66}$

The first edition of his commentary on Paul's letter to the Romans was published in $1540,{ }^{67}$ i.e. not long after the second edition of his Institutio. 'All of his writings betray the growing influence of patristic literature within Calvin's theology. ${ }^{68}$ Calvin was in possession of Chrysostom's opera omnia in Latin, ${ }^{69}$ which

${ }_{64}$ Mitchell, The Heavenly Trumpet, p. 30.

65 Cf. Lim, Public Disputation, pp. I72-3.

66 Karl-Heinz zur Mühlen, "Der Begriff "sensus" in der Exegese der Reformationszeit' (1996), in Reformatorische Prägungen: Studien zur Theologie Martin Luthers und zur Reformationszeit, ed. A. Lexutt and V. Ortmann (Göttingen: Vandenhoeck \& Ruprecht, 20II), pp. 96-Iıо, at Iıо.

${ }_{67}$ Revised editions appeared in $\mathrm{I} 55 \mathrm{I}$ and $\mathrm{I} 556$.

${ }^{68}$ Alexandre Ganoczy and Klaus Müller, Calvins handschriftliche Annotationen zu Chrysostomus: Ein Beitrag zur Hermeneutik Calvins (Veröffentlichungen des Instituts für Europäische Geschichte Mainz, ıо2; Wiesbaden: Steiner, I98I), p. 25.

69 Calvin used Claude Chevallon's edition of the Opera omnia (I536) (cf. Ganoczy and Müller, Calvins handschriftliche Annotationen, pp. 4-I7). Cf. the list of the (collected) works of the Church Fathers used by Calvin in 
he annotated in the manner of the Erasmian reading instructions (underlining, marking, commenting). ${ }^{70}$ Apart from Augustine, it was Chrysostom who most strongly inspired Calvin's own thinking. ${ }^{71}$ In matters of exegesis, though, Calvin relied much more on the judgement of Chrysostom: 'Calvin's almost unqualified respect for Augustine's authority in dogmatic matters is not paralleled in the exegetical realm. Here it is Chrysostom who was Calvin's hero, at least for the New Testament. Augustine's exegesis is severely criticized. He was too subtle, passing over the plain sense of Scripture and indulging in vain speculations. ${ }^{72} \mathrm{He}$ calls Chrysostom the 'most excellent [interpreter] of all'. ${ }^{73}$

If we consult his private copy of Chrysostom's homily on Romans we find but one mark (and none on Romans 4). Does this imply that Calvin was not aware of his favourite exegete's comments? First, we have to consider that Calvin studied various collections of Chrysostom's works and also used other sources that contained excerpts and quotations of his texts ${ }^{74}$ so that his acquaintance with the Church Father and with his exegetical world of thought was far from fleeting. Second, the excellent knowledge of, and respect for, Chrysostom suggests that his insights left their mark on Calvin's commentary on Romans, the more so as it was precisely this Pauline letter that decisively shaped Calvin's theological formation. Third, there are a number of clues that suggest an echo of the Church Father in Calvin's comments on Rom. 4:20. For instance, Calvin has evidently read Chrysostom's homilies on Genesis very closely. Among the 90 underlined passages ${ }^{75}$ there is one that warns not to meddle in

Anthony N. S. Lane, Fohn Calvin: Student of the Church Fathers (Edinburgh: T \& T Clark, I999), pp. II-I2.

${ }^{70}$ Cf. Gilbert Heß, 'Formen der Validierung in frühneuzeitlichen Florilegien', in M. L. Allemeyer, K. Behrens and K. U. Mersch (eds.), Eule oder Nachtigall? Tendenzen und Perspektiven kulturwissenschaftlicher Werteforschung (Göttingen: Vandenhoeck \& Ruprecht, 2007), pp. 73-103, at 76 with n. I2.

${ }^{71}$ See on Calvin's use of the Church Fathers the comprehensive study by Johannes van Oort, 'John Calvin and the Church Fathers', in I. Backus (ed.), The Reception of the Church Fathers in the West: From the Carolingians to the Maurists (Leiden: Brill, I997), vol. I, pp. 66I-700.

72 Cf. Lane, Fohn Calvin, p. 39. Further David C. Steinmetz, 'Calvin and the Patristic Exegesis of Paul', in idem (ed.), The Bible in the Sixteenth Century (Duke Monographs in Medieval and Renaissance Studies, II; Durham, NC: Duke University Press, I990), pp. I00-I 8, 23I-5.

${ }_{73} \mathrm{CR} 37$, col. 834 ('Chrysostomum ex omnibus potissimum delegerim').

${ }^{74}$ Cf. Ganoczy and Müller, Calvins handschriftliche Annotationen, p. 24 (e.g. Peter Lombard, Libri Quattuor Sententiarum; Philipp Melanchthon, Loci Communes).

${ }^{75}$ Ganoczy and Müller, Calvins handschriftliche Annotationen, p. I8. 
divine affairs by saying: 'Why did God create this and that?'; ${ }^{76}$ and another one that recommends not to inquire into the place of Enoch's rapture, but simply to believe what is being said. ${ }^{77}$

Needless to say that the assumption of a factual theological agreement between Calvin and Chrysostom, and even of a possible dependence of Calvin on the Church Father, should not belittle Calvin's own philological and exegetical skills. ${ }^{78}$ In his own commentary on Romans, Calvin explains that Abraham 'neither vacillated nor fluctuated (non vacillasse, aut fluctuatum esse) as we usually do in ambiguous circumstances'. Then he offers an illuminating explanation of the phrase ov $\delta \iota \epsilon \kappa \rho i \theta \eta$ : unlike the Vulgate, he does not use the word 'haesitare', but translates: "non disquisivit ${ }^{\text {'7 }}$ and explains his decision:

Though I do not follow the old version, nor Erasmus, ${ }^{80}$ yet my rendering is not given without reason. The Apostle seems to have had this in view-That Abraham did not try to find out, by weighing the matter in the balance of unbelief, whether the Lord was able to perform what he had promised. What is properly to inquire or to search into (disquirere) anything, is to examine (excutimus) it through diffidence, and to be unwilling to admit what appears not credible (credibile), without thoroughly sifting it.

${ }^{76}$ Cf. ibid., p. 56: In Calvin's edition the Greek pair of words $\pi \epsilon \rho \iota \rho \gamma \alpha \dot{\zeta} \epsilon \sigma \theta \alpha \iota$ and $\pi \circ \lambda v \pi \rho a \gamma \mu o v \epsilon \hat{\imath} v$ is translated as 'obmurmurare, et curiosius inquirere'. It continues: 'et dicere: Quare deus hoc vel illud fecit?' Calvin marked the entire passage and underlined the preceding sentence: 'Alia enim propter nostram utilitatem fecit, alia propter suam magnificentiam.'

77 Cf. ibid., p. 81: Calvin underlined the sentence: 'Iam si quis curiosius rogare [ $\pi \epsilon \rho \iota \epsilon \rho a ́ \zeta \epsilon \sigma \theta \alpha \iota]$ velit et dicere: et quo ipsum [sc. Enoch] transtulit?' The following is marked; it says inter alia: 'discat, non convenire humanis mentibus curiosius ea quae a deo fiunt explorare $[\pi o \lambda v \pi \rho \alpha \gamma \mu o v \in \hat{\imath} \nu]$, sed credere his quae dicuntur'.

78 Despite his reverence for the Church Father, Calvin also criticized a number of his comments (cf. ibid., p. 2 I with examples).

${ }^{79}$ The Latin text of the third edition $(1556)$ is found in Iohannis Calvini Commentarius in epistolam Pauli ad Romanos, ed. T. H. L. Parker (Studies in the History of Christian Thought, 22; Leiden: Brill, I98I). The English translation follows that of John Owen (Calvin's Commentaries: Romans, ed. and trans. John Owen [Grand Rapids, MI: Eerdmans, I947]).

80 See the note in Parker, Iohannis Calvini Commentarius, p. 96, n. 6o: 'Eras[mus] L[atin New Testament $]^{1-5}$ : verum ad promissionem dei non haesitabat incredulitate; Eras[mi] Ann[otationes $]^{1-5}$ : id est, Non diiudicavit aut disquisivit quod est diffidentis...-Vg: in repromissione etiam Dei non haesitavit diffidentia.' (Notably, Calvin only deviates from Erasmus' Novum Testamentum, but not from his Annotationes, as they too have 'disquirere' for

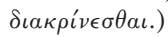


To be sure, Calvin is well aware of the discrepancy between his exposition and Abraham's laughter in view of the promise (Gen. I 7:I7), but he regards Abraham's reaction-unlike Sara's (Gen. I 8: $\left.12-I_{5}\right)^{81}$-as an 'expression of wonder'. ${ }^{82}$ Abraham 'indeed asked, how it could come to pass, but that was the asking of one astonished; as the case was with the virgin Mary, when she inquired of the angel how could that be which he had announced; and there are other similar instances'.

Calvin's exegesis reaches its Reformation peak when he explains

that no greater honour can be given to God, than by faith to seal his truth; as, on the other hand, no greater dishonour can be done to him, than to refuse his offered favour, or to discredit his word. It is hence the chief thing in honouring God, obediently to embrace his promises: and true religion begins with faith (Veraque religio a fide incipit).

According to Calvin, therefore, Abraham did not scrutinize in a distrustful attitude God's promise. He did not offend God with conceited questions and insubordinate examinations.

\subsubsection{Markus Barth}

The reformed theologian Markus Barth (the oldest son of Karl Barth) arguably held John Calvin in high esteem and made extensive use of his exegetical insights. ${ }^{83}$ In the congress volume that documents the already mentioned paper by Joachim Jeremias on Romans 4, we find a remarkable response of Markus Barth to Jeremias, probably formulated ad hoc in the course of the discussion. The line of thought of this response could well be inspired by Calvin's expositions (though Calvin is not cited in this context), yet it incorporates some lexicographical observations and places the Abraham scene into the setting of a law court, thus adding a juridical accent. At first Barth insists-not without some irony-that he considers Jeremias's explanation to be a 'classical account in the line from Augustine to Luther and to all honest confessors, not only of

81 In contrast to Abraham, Sara's laughter has been reproached: '[A] similar laughter and inquiry on the part of Sarah were not without reproof, because she regarded not the promise as valid.'

82 Similarly Philo, Quaest. 3.55 (cf. Douglas J. Moo, A Commentary on the Epistle to the Romans [NICNT; Grand Rapids, MI: Eerdmans, I996], p. 285).

${ }^{83} \mathrm{Cf}$. e.g. the abundant references to Calvin in his two-volume commentary on Ephesians (Markus Barth, Ephesians, 2 vols. [AB 34; Garden City, NY: Doubleday, 1974]). 
the Reformation but also among Catholics'. ${ }^{84}$ His criticism sets in where he recognizes an understanding of faith as a 'disposition of the $\psi v \times \eta^{\prime}$ ' the opposite of which is doubt. ${ }^{85}$ The Old Testament, he argues, does not have a word for 'doubt', but expresses the opposite of faith, of 'being firm' or 'fastening oneself' by means of the idea of 'wavering' or 'fluctuating' ('Schwanken' and 'Wanken'). ${ }^{86}$

If in Romans 4 doubt is the opposite of faith, this would imply an innovation of Paul which would not correspond to his exposition of the nature of faith by means of Abraham and Old Testament texts! If Paul argues on the basis of the Old Testament, and if indeed he is a reasonably good exegete, he has to argue in line with the Old Testament. If, however, he introduces something new such as the Greek concept of doubt over against the certainty of faith, then he factually abuses the Old Testament. ${ }^{87}$

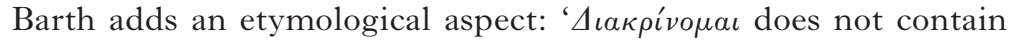
the root "two", - like 'zweifeln', 'douter', or 'to doubt'—but 'etymologically it says: "here is someone who pronounces a judgement" and "here is someone who gives a response"-indeed a negative response, which rebukes someone else's judgement to his own detriment. ${ }^{88}$

Paul is best understood, according to Barth, if one translates: Abraham

would have acted up as opposing judge (Gegenrichter) against God's promise if he had not believed, or: he did not challenge God like a know-it-all (Besserwisser). This would stretch beyond the psychology of doubt and lead back to the situation of judgement [of Romans 3]...: Here is God with his promise and the question: How are we responding? Do we say: I accept this promise as right? ${ }^{89}$

Later, Barth picks up this thought and recapitulates his objections against the traditional understanding: 'The opposite of faith is to not accept God's judgement or juridical order, to not live from it, but to think that one knows it all. Hence, I would say: this kind of contradiction, this acting up as an

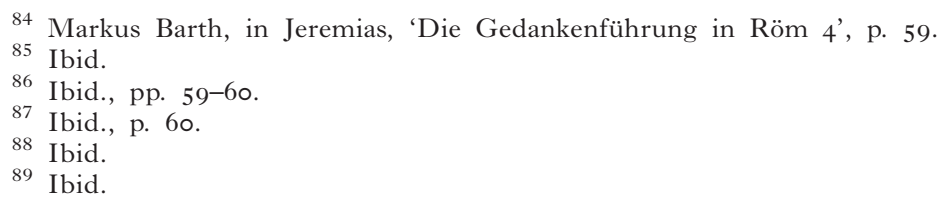


opposing judge, is different from doubting and saying: "Should I accept it or should I not?" It is active resistance against God., 90

Thus, according to Barth's line of thought, Abraham did not go up against God by claiming superior knowledge, and he did not oppose God by questioning and seeking to overturn his decree.

\subsection{Interpretative Suggestions}

The exegesis of Chrysostom, Calvin, and Barth confirms that

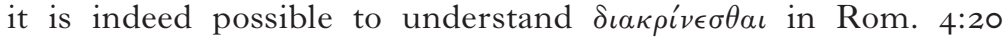
within the classical/Hellenistic semantic paradigm. It is not necessary to appeal to the generative power of the gospel, to posit a semantic shift in the New Testament, or to postulate a semantic development in contemporary Greek popular speech. This observation is even more significant than the intriguing question whether or not these three commentators are 'genealogically' linked. Chrysostom connects this verb with the act of curious questioning and immoral meddling in divine affairs, Calvin understands it as inquiring into the promise and only accepting those things that appear credible upon a thorough examination, and Barth finally insists that it stands for acting up as a Gegenrichter against God's promise, indeed as 'active resistance against God'.

Explicitly or not, their interpretations all refrain from limiting the semantics of $\delta \iota \alpha \rho i v \in \sigma \theta \alpha \iota$ to an intrapersonal conflict or divisiveness, or to the 'two-ness' of one's heart or mind. Meddling, inquisitiveness, and rebellion are not the same as the mental disposition of indecisiveness. They are not the same as the notion of 'contending or disputing with oneself', 91 of 'being undecided within oneself', ${ }^{92}$ or of 'being divided against oneself', ${ }^{93}$ as the dictionaries imply. They are not the same as 'hesitating' (Vulgate) or 'staggering' (KJV) or 'wavering' (NRSV, ESV, NAS, etc.), as the translations suggest. Finally, they are not the same as 'being undeterred', ${ }^{94}$ as adapting an 'attitude of distrust and inconsistency in relationship to God and

${ }^{90}$ Ibid., p. 65.

91 Bauer, Wörterbuch, p. 370. This and the following two references are found in Spitaler, ' $\triangle \iota \alpha \kappa \rho i v \in \sigma \theta \alpha \iota^{\prime}$, p. $4, \mathrm{nn} .7$ and 8.

92 Cf. Timothy Friberg, Barbara Friberg, and Neva F. Miller, Analytical Lexicon of the Greek New Testament (Baker's Greek NT Library; Grand Rapids, MI: Baker, 2000), p. I Iо.

${ }^{3}$ Cf. James Hope Moulton and George Milligan, The Vocabulary of the Greek New Testament Illustrated from the Papyri and other Non-Literary Sources (London: Hodder \& Stoughton, I9I4-29), p. I50.

94 Jeremias, 'Die Gedankenführung in Röm 4', p. 57. 
his promises'95 or as experiencing 'weakness in faith', 96 as many commentaries contend.

Is it at all something that can be labelled 'doubt'?

\subsection{Abraham's Faith}

My own suggestion starts from the antonym of $\delta \iota \alpha \kappa \rho i v \epsilon \sigma \theta \alpha \iota$ that occurs in Rom. 4:20, namely $\pi i \sigma \tau \iota s$ (and $\pi \iota \sigma \tau \epsilon \dot{v} \epsilon \iota$ ). On the one hand, in Rom. 4:I8-2I(22), Paul explores Abraham's modus fidei from its beginning as response to God's promise to the desolation of its non-fulfilment. Since Paul extracts and selects the motifs of his presentation from the Old Testament story, ${ }^{97}$ the result is not an a-historical, abstract definition of faith, but a description of faith bound to Abraham's biography. ${ }^{98}$ On the other hand, on the basis of Abraham's biography, Paul creates a comprehensive theologia fidei, as Abraham's faith typologically prefigures Christian faith. ${ }^{99}$ When Paul quotes Gen. I 5:6a, 'and Abraham believed (' $\epsilon \pi i \sigma \tau \epsilon v \sigma \epsilon \nu)$ ', he has in mind the act of coming to faith, his transition from the sphere of unbelief ( $\alpha \pi \iota \sigma \tau i \alpha$, cf. Rom. 3:3) and ungodliness (áć) $\beta \iota \iota$, cf. Rom. 4:5) to the sphere of faith, his first encounter with the reality of faith. ${ }^{100}$ The aorist $\epsilon \pi i \sigma \tau \epsilon v \sigma \epsilon \nu$ is an ingressive aorist. ${ }^{101}$ Abraham remained in the dominion of ungodliness as long as faith did not govern his life, as long as he did not live under the domain of faith.

95 Moo, Epistle to the Romans, p. 285.

96 Cf. Ulrich Wilckens, Der Brief an die Römer, vol. I: Röm I-5 (EKK 6/1;

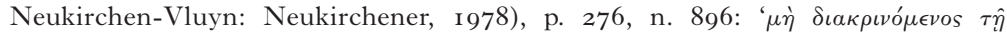

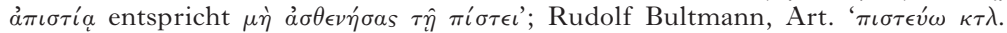
A, C, D', TWNT 6, pp. I74-82, I97-230, at 207; Ernst Käsemann, An die Römer (HNT 8a; 4th edn.; Tübingen: Mohr Siebeck, I980), p. II 8.

97 Such 'selective and dramatic retelling of biblical stories was quite common in Jewish literature of this period' (Thomas H. Tobin, 'What Shall We Say that Abraham Found? The Controversy behind Romans 4', HTR 88 [1995], pp. 437-52, at 449, listing passages from fubilees, Philo, and Josephus).

98 Cf. Jeremias, 'Die Gedankenführung in Röm 4', p. 55.

99 Cf. Ernst Käsemann, 'Der Glaube Abrahams in Röm 4', in Paulinische Perspektiven (Tübingen: Mohr Siebeck, I969), pp. I40-77, at I4I. See also Fritz Neugebauer, In Christus = En Christoi: Eine Untersuchung zum paulinischen Glaubenverständnis (Göttingen: Vandenhoeck \& Ruprecht, I96I), p. I68-9: 'Abraham [ist] der Typus des neuen Gottesvolkes.'

100 Cf. Hermann Binder, Der Glaube bei Paulus (Berlin: Evangelische Verlagsanstalt, I968), p. 64.

101 Klaus Haacker lists analogous usages of the aorist of $\pi \iota \sigma \tau \epsilon \dot{v} \epsilon \iota$ (idem, Art. 'Glaube II/3. Neues Testament', TRE I3, pp. 277-304, at 297): Acts 2:44 [v.l.]; 4:4, 32; 8:I2, I3; 9:42; II:I7, 2I; I3:I2, 48; I4:I; I5:7; I6:3I; I 7:I2, 34; I8:8; I9:2, 4; Rom. Iо:I4; I3:II; I Cor. 3:5; I 5:2, II; Gal. 2:I6; Eph. I:I3; 2 Thess. I:Io; Heb. 4:3; II:I6; I John 3:23 (?); Jude 5. 
Paul follows the widespread Jewish tradition that Abraham turned from paganism to the true God, ${ }^{102}$ but also seems to have been aware of a topos in Jewish exegesis according to which the events reported in Genesis $\mathbf{5}_{5}$ happened prior to Abraham's migration from Haran reported in Genesis I 2. ${ }^{103}$ All this implies that Genesis I5 marks, for Paul, the beginning of Abraham's journey to, and in, faith.

Paul takes up a thought from the beginning of his letter: ${ }^{104}$

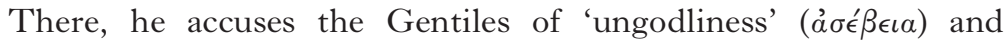
'unrighteousness' ( $\left.\alpha \delta \delta_{\iota} i^{\prime} \alpha\right)$; they suppress the truth of God's faith-

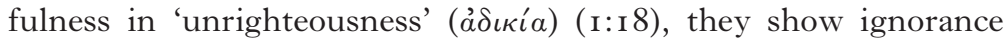

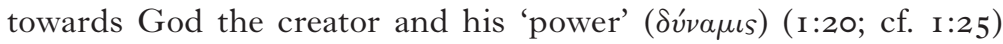

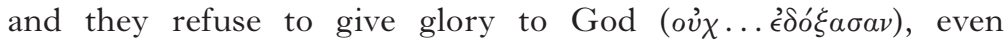
though they know him (I:2I). By contrast, Abraham once and for all left behind this negative sphere, renounced the neglect of God, and set off to a new existence outside of his former

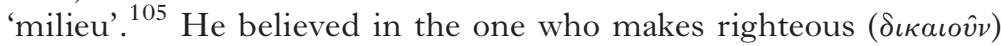
the 'ungodly' ( $\left.a \epsilon \epsilon \beta \eta_{s}\right)$, clinging to God's promise and accepting its truth in faith. He knew that he stood empty-handed before God

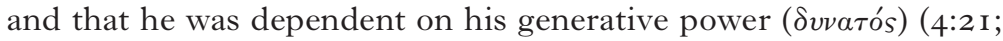

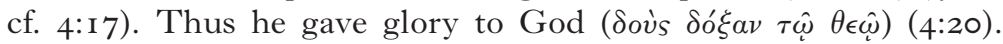
Apparently, there is a clear 'structural pattern of contrast between Abraham and the rebellious Gentiles': 'Abraham, in his

102 Edward Adams gathers passages from Jewish texts which interpret Gen. II:27 - I 2:9 as Abraham's rejection of idolatry and turning to the creator God (Fub. I1.16-І7; г2.I-2I; Philo, Virt. 21 I-I6; Abr. 68-72; Her. 97-9; Josephus, Ant. I.155-6; ApcAbr. 7.10-I2) (idem, 'Abraham's Faith and Gentile Disobedience: Textual Links between Romans I and 4', FSNT 65 [1997], pp. $47-66$, at 55-9).

103 This view is inspired by the differences of the time spans in Gen. I5:I3 (400 years) and Exod. I2:40 (430 years). Paul seems to have been aware of such Jewish numerical calculations and in particular of the combination of Gen. I 5:13 and Exod. I2:40 (cf. Stefan Kreuzer, "Der den Gottlosen rechtfertigt" (Römer 4,5): Die frühjüdische Einordnung von Gen I5 als Hintergrund für das Abrahambild und die Rechtfertigungslehre des Paulus', TBei 33 [2002], pp. 208-I9, at 2I8-I9): In Gal. 3:I7 he relates the 430 years to the time span between promise and law, i.e., between Abraham and Moses, an inference which cannot be deduced from Exod. I 2:40 alone.

${ }^{104}$ This is commonly accepted. Klaus Haacker (Der Brief des Paulus an die Römer [THKNT; Leipzig: Evangelische Verlagsanstalt, I999], p. I o9, n. II I) refers to the commentaries of C. K. Barrett, C. E. B. Cranfield, James D. G. Dunn, Joseph A. Fitzmyer, Ernst Käsemann, Franz-J. Leenhardt, Douglas J. Moo, Leon Morris, Anders Nygren, and Ulrich Wilckens.

105 Cf. Kreuzer, “'Der den Gottlosen rechtfertigt", , p. 2 I9. 
trustful response to God, did precisely what the disobedient Gentiles of Rom. I.18-32 declined to do., ${ }^{, 106}$

Yet Paul not only contrasts 'Abraham's faith and the Gentiles' failure', ${ }^{107}$ but also confronts 'Jacob's [i.e. Israel's] ungodliness' (cf. I I:26) ${ }^{108}$ In the passage Rom. 3: I-8, which consists of 'hard questions with existential bite for his own faith ${ }^{109}$ and which 'clearly anticipates his lengthy discussion of the enduring validity of God's promises to Israel in Romans 9-I I' ${ }^{110}$ Paul deplores the 'faithlessness' ( $\alpha \pi \iota \sigma \tau i \alpha)$ of 'some' Jews, as they dispute the faithfulness ( $\pi i \sigma \tau \iota s)$ of God (3:3) and stand iniquitously and in unrighteousness $\left(\alpha \delta \iota \iota^{\prime} \alpha\right)$ before him (3:5). In the person of Abraham this is reverted: through his faith he acknowledges the truth of God (cf. 3:3: o $\theta \epsilon o \dot{s} \alpha \dot{\lambda} \eta \theta \eta^{\prime} s$ ) and hence subscribes to LXX Ps. 50:6, which Paul quotes in 3:4: 'So that you may be justified $(\delta \iota \kappa \alpha \iota \omega \theta \hat{\eta} s)$ in your words, and prevail in your judging ( $\epsilon \nu \tau \hat{\omega} \kappa \rho i v \epsilon \sigma \theta \alpha i \quad \sigma \epsilon)$ ' (Rom. 3:4). This is why Abraham himself is

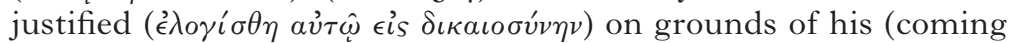
to) faith $(\dot{\epsilon} \pi i \sigma \tau \epsilon v \sigma \epsilon \nu)(4: 3)$.

Paul is quite clear: all have sinned and are apart from God, both Gentiles and Jews; their ungodliness is, in Paul's view, not merely a passive being apart from God, but an active denial of his godliness. This is precisely what Paul intends to say with the dative $\tau \hat{\eta} \dot{\alpha} \pi \iota \sigma \tau i \dot{\alpha}$ in Rom. 4:20. Several commentators such as

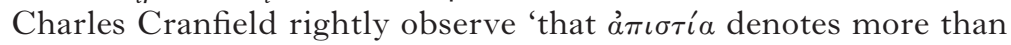
just the absence of faith: it denotes the active rejection of faith, the positive refusal to give credence to God's offered promise'.111 Mostly, it is argued that ' $\tau \hat{\eta} \dot{a} \pi \iota \sigma \tau \tau^{\prime} a$ is probably a relatively rare example of the causal dative', ${ }^{112}$ though few recognize that it

106 Adams, 'Abraham's Faith', pp. 54, 47.
107 Ibid., p. 47.

108 The noun $\alpha \sigma \epsilon \epsilon \epsilon \iota \alpha$ occurs twice in Paul: Rom. I:I8 and I I:26, once denoting Gentile ungodliness, once Israel's ungodliness (cf. in addition Rom. $4: 5 ; 5: 6)$.

109 James D. G. Dunn, Romans (WBC; Dallas, Texas: Word, I988), p. I29.

110 Mark A. Seifrid, 'Unrighteous by Faith: Apostolic Proclamation in Romans I:18-3:20', in Fustification and Variegated Nomism, pp. 105-46, at ro7.

111 C. E. B. Cranfield, A Critical and Exegetical Commentary on the Epistle to the Romans, vol. I (ICC; Edinburgh: T \& T Clark, I975), p. 248, with reference to Otto Michel, Der Brief an die Römer (KEK; 5th edn.; Göttingen:

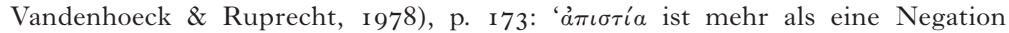
von $\pi i \sigma \tau \iota s:$ gemeint ist die Absage an den Glauben, der Verzicht auf die angebotene Verheißung Gottes.'

112 Moo, Epistle to the Romans, p. 284, n. 79; cf. BDR §I96.I; Eduard Lohse, Der Brief an die Römer (KEK 4, Göttingen: Vandenhoeck \& Ruprecht, 2003), p. I6o, n. 7 . 
could also be a dative of "sphere", ${ }^{113}$ I think that a 'spatialdynamic' thinking is not only at the root of Paul's 'in Christ' terminology, but also of his language of faith: as Christians we are 'in faith' (2 Cor. I $3: 5$ ), live 'in faith' (Gal. 2:20), and stand 'in faith' (Rom. I I:20; I Cor. I6:I3; 2 Cor. I:24), just as we are 'in Christ', live 'in Christ' (Rom. 6:I I), and stand 'in Christ' (Phil. 4:I; I Thess. $3: 8$ ). Faith for Paul not only serves two functions, 'one individual and one communal', ${ }^{114}$ but three: one individual, one communal, and one salvation-historical. For Paul, $\pi \iota \sigma \tau \iota s$ is not only a 'disposition'-individual or corporate-but also a salvation-historical 'dispensation', the signature of the new phase of God's dealing with humanity, which transforms the conditions of human existence and which draws human beings into its sphere of influence (cf. esp. Gal. 3:23-6). ${ }^{115}$ Its opposite, $\alpha \pi \iota \sigma \tau i ́ a$, stands for the sphere of ungodliness and depravity, in which God's wrath and human sin are effective. Abraham is described by Paul as the 'pre-existent' or 'primordial' member of the realm of faith, as both typos and example of those who ground their existence 'in faith', of those who are $\epsilon^{\kappa} \kappa \pi^{\prime} \sigma \tau \epsilon \omega{ }^{116}$

\subsubsection{Abraham and 'Doubt'}

What are the consequences that can be drawn from this 'spatial-dynamic' —and, as it were, 'existential-ontological' ${ }^{117}$ — view

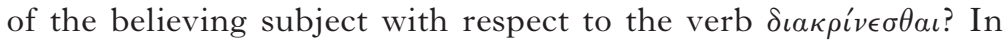
this final step, the various argumentative threads presented in the course of this study are gathered and bound together in terms of a (tentative) solution to the understanding of $\delta \iota \alpha \kappa \rho i v \epsilon \sigma \theta \alpha \iota$ in Rom. 4:20.

If it is true that ' $a \pi \iota \sigma \tau i$ ' $a$ denotes more than just the absence of faith', but rather an existence apart from the domain of faith, then $\delta \iota \kappa \kappa \rho i v \epsilon \sigma \theta a \iota$ must be more than 'an uncertainty of belief or opinion' or 'a lack of confidence' or 'an inclination not to believe

113 Moo, Epistle to the Romans, p. 284, n. 79. But see Moo's translation, which once again accentuates Abraham's disposition: 'he did not waver "in" the attitude of disbelief'.

114 Ben C. Dunson, 'Faith in Romans: The Salvation of the Individual or Life in Community?', $\mathcal{F S N T} 34$ (2011), pp. 19-46, at 22.

115 This understanding of $\pi i \sigma \tau \iota s$ ties in with a specific interpretation of the enigmatic syntagma $\pi i \sigma \tau \iota s \mathrm{X} \rho \iota \sigma \tau o \hat{v}$, which cannot be detailed in this context;

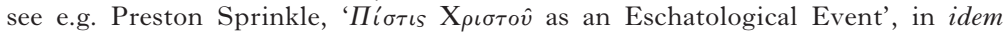
and M. F. Bird (eds.), The Faith of Fesus Christ: Exegetical, Biblical and Theological Studies (Peabody, MA: Hendrickson, 2009), pp. I65-84.

116 Cf. Schliesser, Abraham's Faith, p. 328.

117 Cf. Ingolf U. Dalferth, Die Wirklichkeit des Möglichen: Hermeneutische Religionsphilosophie (Tübingen: Mohr Siebeck, 2003), p. 420. 
or accept'. ${ }^{118}$ It must be more than a struggle in the inner life generated by the contrariety of reality. Rather, if Abraham had moved from faith toward unbelief, he would have returned to that stage in his life which he had left behind through his coming to faith upon God's promise (4:3); he would have returned into Gentile ungodliness and unrighteousness (I:I8), this negative sphere that Paul has described in Rom. I:I8-32. Also, he would have relapsed into the unrighteousness $(\dot{a} \pi \iota \sigma \tau i \alpha)(3: 5)$ and ungodliness (I I:26) of those 'Jews', who oppose God and his decrees $(3: 3-4)$ and do not know about the 'righteousness of God' ( I $0: 3$ ).

As mentioned above, Chrysostom expressed his concern about people who tend to meddle in the mysteries of God's work and being and engage in curious questioning and speculations about God, the creator; such insubordinate audacity is futile and will bring about God's punishment. Only faith is able to control human curiosity and insolence and avert their suffering. Therefore, only through faith, God is glorified. One passage in Chrysostom succinctly summarizes his thoughts: 'glorifying God is this: always yielding one's own thinking to what is incomprehensible and to the inexpressible power and wisdom, and neither interfering nor meddling with God's affairs nor saying, why this? for what purpose that? how can this be?"119 This description reminds us of what the Gentiles of Rom. I:I8-32 are accused of: They do not glorify God, the creator (I:2 I), but rather claim to have wisdom on their own ( $1: 22)$; they meddle in the divine ordinances and order of creation by exchanging the truth about God for a lie (I:25).

Nevertheless, according to Paul they know God's decree 'that those who practise such things deserve to die' (I:32). I suggest that Chrysostom's comments point to a decisive semantic aspect

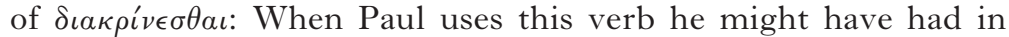
mind that Abraham did not act up as a 'busybody' or 'meddler'. $\mathrm{He}$ respected the asymmetrical relation between creature and creation (cf. Rom. 9:20) and did not interfere with the one, 'who gives life to the dead and calls into existence the things that do not exist' (Rom. 4:I7). He did not return to the sphere of unbelief and ungodliness, but—as Käsemann put it—accepted

118 See above, n. 22 .

119 Ad eos qui scandalizati sunt 10.7.5-9 (Fean Chrysostome. Sur la providence de Dieu, ed. and trans. Anne-Marie Malingrey [SC 79; Paris: Cerf, ig6r], pp. 52-276; English translation in Spitaler, ' $\Delta \iota \alpha \kappa \rho \iota ́ v \epsilon \sigma \theta \alpha \iota '$, p. 27). 
that God is God ${ }^{120}$-in short: 'he did not in a meddlesome attitude argue (with God, the creator) in unbelief (ov $\delta \iota \epsilon \kappa \rho i \theta \eta \tau \hat{\eta}$

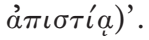

A specific form of meddling with the divine affairs is entering into a legal dispute with God, the judge. This is what Markus

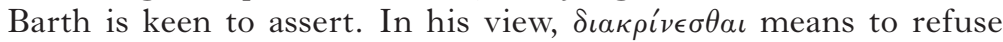
God's promise, saying: 'I do not accept God's word to be true or right.' 'The rejection of the promise is inextricably linked to one's own detriment. It seems that Barth builds his argument on his reading of Rom. I:I 8-3:20 in general-a passage which is pervaded by forensic language and imagery ${ }^{121}$ —and on Rom. $3: 1-8$ in particular. In Rom. 3:6 'it is obvious that God's righteousness as Judge is the fundamental axiom from which Paul moves out and which he seeks to defend despite the corollaries which might be drawn from Israel's unfaithfulness $(3 \cdot 3-6)$ '. ${ }^{122}$ Despite, or rather: Because of Israel's unfaithfulness to the oracles of God (Rom. 3:2), he will prevail in his judging (3:4), and all those who seek to turn God into a liar will have to realise that eventually he will be found true. At the end of this passage, Paul exclaims: 'Their condemnation is just!' $(3: 8)$. Barth's interpretation, therefore, draws on another significant nuance of the semantics of

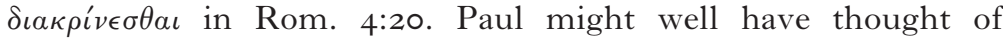
Abraham as a figure who did not act up as an 'opposing judge'. Rather, he accepted the oracles of God in faith and was therefore reckoned righteous by God. Consequently, 'he did not in an insolent manner dispute (with God, the judge) in unbelief

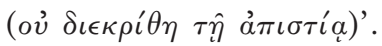

In sum, the line of argument of the first chapters of Romans shows that the apostle is less concerned with the psychology of faith than with the question of how human beings position themselves before God. Do they hear and yield to his word or do they adopt a rebellious and disobedient attitude? Do they live in the 'sphere of Adam' or in the 'sphere of Christ', as typologically prefigured by Abraham? ${ }^{123}$ The recipients of the letter were not prepared to get a glimpse into the psyche of their forefatherdoes it display uncertainty, hesitation, wavering?-but they are eager to know which side he takes in the face of the provocative

120 Cf. Käsemann, Römer, p. I4I.

121 Seifrid, 'Unrighteous by Faith', p. Io8 with n. 7.

122 James D. G. Dunn, 'Jesus the Judge: Further Thoughts on Paul's Christology and Soteriology' (200I), in idem, The New Perspective on Paul (Tübingen: Mohr Siebeck, 2005), pp. 389-407, at 399.

123 Cf. Morna D. Hooker, From Adam to Christ: Essays on Paul (Cambridge and New York: Cambridge University Press, I990), p. 4I. 
impossibility of God's promise: Does he become weak in and fall off from faith? Does he move back into the realm of 'unbelief', separating himself from and arguing with God? Or does he stand firm in faith, being strengthened by God?

A comparison of Paul's argumentation with expositions of contemporaneous and later Jewish sources illustrates the differences and commonalities in their approaches. Philo's Abraham embodies 'the best elements of Greek philosophy', ${ }^{124}$ strives for the Hellenistic virtues, and at the same time believes in the 'Uncreated' (Virt. 21 $8^{125}$ ), the 'Existent' (Abr. 270). Abraham, 'having gained faith, the most sure and certain of the virtues, he gained with it all the other virtues'-'because of his greatness of soul' (Virt. 216). One of Philo's numerous citations and expositions of Gen. I 5:6 is particularly illuminating with respect to the question of Abraham's 'doubt'. Philo links this verse with Gen. I 7:I7: 'Then Abraham fell on his face and laughed, and said in

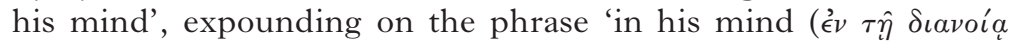
av่ $\tau \circ \hat{v})^{\prime}:$ This addition

is made with very careful purpose. Why so? Because in saying 'Shall

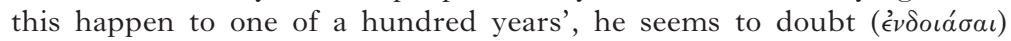
the birth of Isaac in which in an earlier place he was said to believe [sc. Gen. I 5:6]... So then, since doubt was not consistent with his past belief, Moses has represented the doubt not as long-lived, or prolonged to reach the mouth and tongue, but staying where it was with the swiftly moving mind... So then in the case of the virtuous man the swerving was short, instantaneous and infinitesimal, not belonging to sense but only to mind, and so to speak timeless.

Philo goes on: The one who argues that Abraham did not have 'any trace or shadow or breath of unbelief whatsoever' wishes to 'make out the created to be uncreated, the mortal immortal, the perishable imperishable... man to be God. Such a person asserts that the faith which man possesses should be so strong as to differ not at all from the faith which belongs to the Existent, a faith sound and complete in every way' (Mut. I77-8I). Since Philo understands faith as a $\delta \iota \alpha \dot{\theta} \theta \sigma \iota s$ of the soul, ${ }^{126}$ he expends much exegetical energy in exploring the inner life of the patriarch; 'doubt' is an aspect that he embarks upon in numerous other places and with a propensity to detail. ${ }^{127}$ Obviously, such

\footnotetext{
124 G. Walter Hansen, Abraham in Galatians: Epistolary and Rhetorical Contexts (JSNTSup 29; Sheffield: JSOT Press, I989), p. I90.

125 Trans. Francis H. Colson/George H. Whitaker.

126 Cf. Bultmann, Theology, p. 3 I 6.

127 Cf. e.g. Virt. 216; Her. IоI; $Q G 3.2 ; 3.58 ; 4.17$.
} 
deliberations about the complexities and nuances of Abraham's interior are not in Paul's focus.

A different perspective on Abraham's attitude is taken by those Jewish sources which regard the questions raised by Abraham in Genesis I 5-particularly Gen. I 5:8: 'How shall I know...?'-as the trigger for divine punishment. ${ }^{128}$ Those texts do not adhere to an idealized image of the patriarch, but rather emphasize the less positive aspects of the biblical text. ${ }^{129}$ However, they do not focus on the 'doubt' of Abraham, but rather on his conduct towards God and on the manner of his interaction with God: the Babylonian Talmud quotes an authority called Samuel, who reflects on the question 'How come our father Abraham was punished and his children subjugated in Egypt for two hundred and ten years?' Samuel responds: 'Because he exaggerated in testing the traits of the Holy One, blessed be He: "And he said, Lord God, how shall I know that I shall inherit it". 130 Several late rabbinic texts explicitly state that Abraham's question was a sinful and improper act or an expression of unbelief. Seder Eliyahu Rabbah argues: 'A man should always take care not to yield to the power of sin, and be it the slightest sin. Come and learn from our forefathers: They went down to Egypt only because of a slight word which Abraham spoke: "How shall I know?",131 A similar thought is found in Seder Eliyahu Zuta: 'Because he said something

\footnotetext{
128 The sources quoted in the following are gathered in Günter Stemberger, 'Gen 15 in Rabbinic and Patristic Interpretation' (2009), in Fudaica Minora, vol. I: Biblische Traditionen im rabbinischen Fudentum (TSAJ I33; Tübingen: Mohr Siebeck, 2010), pp. 452-68, at 462-3; Lewis M. Barth, 'Genesis I 5 and the Problem of Abraham's Seventh Trial', Maarav 8 (1992), pp. 245-63, at $258-62$.

129 To be sure, witnesses to the opposite procedure, i.e. texts which omit or suppress the negative aspects of the biblical portrayal of the patriarch, are more frequent. Interestingly, within this group of writings, some later ones probably 'had knowledge of the traditions that speak of Abraham's fears and lack of faith. Their decision to avoid problematic verses can be explained as an example of their determination to build on positive images of Abraham in biblical and rabbinic traditions' (Barth, 'Genesis I5', p. 262; e.g. Pirqe Rabbi Eliezer).

${ }^{130}$ b. Ned. 32a (trans. Jacob Neusner). Rashi writes in his famous Talmud commentary on this passage: 'he thought excessively about the attributes of the Holy One Blessed be He' (Marcus Jastrow, A Dictionary of the Targumim, the Talmud Babli and Yerushalmi, and the Midrashic Literature [New York: Pardes, I950], p. I222b). Note the correspondence to Chrysostom's warnings not to interfere with God's sovereignty.

131 S. Eli. Rab. I4 (trans. Meir Friedmann).
} 
improper, his sons went down to Egypt.'132 Targum PseudoFonathan claims that the codicil of slavery is a result of Abraham's unbelief: 'Know for certain that your children will be residents in a land that is not theirs, because you did not believe, and they will be enslaved and afflicted four hundred years.' ${ }^{133}$

These features of the assessment of Abraham's faith obviously run directly counter to Paul's statement that Abraham did not in a disrespectful manner argue with God (ov่ $\delta \iota \epsilon \kappa \rho i \theta \eta)$. Günter Stemberger maintained that ' $[\mathrm{t}]$ he development of rabbinic interpretation of Gen 15:6.8 may at least to some extent be understood as a reaction to Christian interpretation'. He has in mind Christian authors such as Ephrem the Syrian, but in my opinion it is not implausible that one characteristic of Paul's Abraham (and not only of the Abraham of Paul's interpreters) stood before the eyes of, and was rejected by, those Jewish authors. Notably, the opposite-'Pauline'-trait of the Jewish Abraham image is reflected in the addition to Gen. I5:6 in Targum PseudoFonathan. This addition is incongruent with the paraphrase of Gen. I 5:I3 mentioned above, but strikingly resembles our proposed interpretation of $\delta \iota \alpha \rho i \nu \in \sigma \theta \alpha \iota$ : 'He had faith in the Memra of the Lord, and he reckoned it to him as merit because he did not speak rebelliously against him. ${ }^{134}$ The Targum's construallater and elsewhere thrown into reverse-seems to be much closer to Paul than the sophisticated analysis of Abraham's inner life in Philo.

\section{Concluding Remarks}

At the end of this tour d'horizon we must return to the question of 'doubt'. Meddling, inquisitiveness, and rebellion are not the same as the shapes of doubt illustrated above, i.e. they are different from Monsignor Quixote's riddles, Descartes' philosophical method, Luther's afflictions, or a fashionable sceptical lifestyle. They are different from our common perception of doubt. If, however, we allow for a wider definition of doubt, this nomenclature might still be applicable.

And indeed, the correlation between doubt in the word of God and dispute against God is a central theme in Reformation theology; it has already surfaced in our discussion of Calvin's

132 S. Eli. Zut. 2 (trans. Meir Friedmann).

133 Tg. Ps.-F. Gen. I 5:13 (trans. Michael Maher).

134 Tg. Ps.-F. Gen. I 5:6 (trans. Michael Maher). 
commentary, where he argued that 'doubt' means to inquire and to search into God's promise through diffidence (disquirere) and that 'no greater dishonour can be done to him, than to refuse his offered favour, or to discredit his word'. In an even more radical manner, Martin Luther unfolds this line of thought in his grand lecture on Genesis (1535-45). There, he explains that Adam's fall set in with the question of the sanctimonious serpent: 'Has God indeed said?' (Gen. 3:I). Adam's sin was not the eating of the fruit, but his engaging in the serpent's question, his challenging and doubting God's word. ${ }^{135}$ According to Luther, 'doubt transforms into unbelief, if it disengages itself from the relationship with God... Those who take matters into their own hands, who seek to establish themselves, they believe that they can dispense with listening and responding. ${ }^{136}$ Adam claimed autonomy and 'began to "argue about God"', and so-as Bultmann comments- he 'set himself outside God and made God's claim upon men a debatable problem'. ${ }^{137}$ There is a kind of doubt that transforms into a sinful dispute; doubt as a trustful and intimate disputare (cum deo) 'in faith' may lead to doubt as a distanced and rebellious disputare (de deo) 'in unbelief'. This is where theologically 'doubt' and 'dispute' overlap, and at the same time this is what separates Adam, the 'paradigmatic sinner', from Abraham, the 'paradigmatic believer': contrary to Adam, Abraham did not set himself outside God 'in unbelief' through doubt and dispute, but rather maintained a strong and trustful salvific relationship with God.

Yet this is a theological thought and not a philological one, a question of interpretation and not of lexicography.

135 Cf. Oswald Bayer, Martin Luthers Theologie: Eine Vergegenwärtigung (3rd edn.; Tübingen: Mohr Siebeck, 2007), p. I62 (referring to WA 42, I20.25I22.19).

136 Bayer, Martin Luthers Theologie, p. 162.

137 Rudolf Bultmann, 'What does It Mean to Speak of God?', in Faith and Understanding, vol. I, trans. Louise P. Smith (New York: Harper \& Row, I969), pp. 53-65, at 54= 'Welchen Sinn hat es, von Gott zu reden?' (I925), in idem, Glauben und Verstehen. Gesammelte Aufsätze, vol. I (Tübingen: Mohr Siebeck, 1933), pp. 26-37, at 27. 